Article

\title{
Environmental and Political Determinants of Food Choices: A Preliminary Study in a Croatian Sample
}

\author{
Marijana Matek Sarić ${ }^{1}$, Krešimir Jakšić ${ }^{2}$ (D) Jelena Čulin ${ }^{3, *}$ (i) and Raquel P. F. Guiné ${ }^{4}$ (i) \\ 1 Department of Health Studies, University of Zadar, 23000 Zadar, Croatia; marsaric@unizd.hr \\ 2 Department of Psychology, University of Zadar, Obala kralja Petra Krešimira IV. 2, 23000 Zadar, Croatia; \\ kresimir.jaksic@gmail.com \\ 3 Maritime Department, University of Zadar, 23000 Zadar, Croatia \\ 4 CERNAS Research Centre, Polytechnic Institute of Viseu, Campus Politécnico, Repeses, 3504-510 Viseu, \\ Portugal; raquelguine@esav.ipv.pt \\ * Correspondence: jculin@unizd.hr
}

Received: 15 September 2020; Accepted: 20 November 2020; Published: 22 November 2020

check for updates

\begin{abstract}
Production, processing, transporting, selling, and consumption of food are highly resource intensive. Therefore, if they are not well managed the consequences for the environment are far-reaching. This study aimed at investigating behaviors and attitudes of the Croatian population concerning the influence of environmental and political determinants of food choices, and the socio-demographic factors associated with pro-environmental behavior. Data analysis involved a non-probabilistic sample of 1534 adult participants from Croatia who responded to a validated questionnaire from November 2017 to March 2018. To test differences between sociodemographic groups, Welch's $t$-test (two groups) and ANOVA (multiple groups) were used. The relationship between age and motivators of food choices was analyzed with Pearson's $r$ correlation coefficient. Participants reported a neutral rate of agreement with the items, with the exception of items related to food waste and food origin, for which they expressed a moderate amount of agreement. Socio-demographic factors that influence environmentally or politically concerned food choices in our study were age (older participants, $p<0.001$ ), gender (women in comparison to men, $p<0.05$ ), education level (higher education in comparison to elementary/high school, $p<0.05$ ), marital status (married/cohabiting in comparison to unmarried, $p<0.05$ ), responsibility for food supply (those who are responsible for food supply in comparison to those who are not responsible for food supply, $p<0.05$ ), eating practices (participants with specific eating practices in comparison to participants without specific eating practices, $p<0.05$ ), and smoking (those who have never smoked score and those who used to smoke in comparison to active smokers, $p<0.05)$. The results show that there are no statistically significant differences in environmental and political determinants of food choices based on the place of residence and employment status. The findings indicate that environmental and political determinants do not play a significant role in the food choices among the Croatian population.
\end{abstract}

Keywords: pro-environmental behavior; environmentally friendly food; food choices; survey

\section{Introduction}

The present global food system is unsustainable, and there is a need to reshape it to enhance its economic, social, and environmental sustainability [1,2]. Consistent with this, eight of the 17 United Nations' Sustainable Development Goals (SDGs) adopted in 2015 are directly or indirectly related to food security and sustainability.

In the European Union, there are high levels of food security and safety, and consumers have a wide choice of food products [3]. However, the environmental, economic, and social aspects of the food 
system must be substantially changed to achieve a sustainable food system. Production, processing, transporting, selling, and consumption of food are highly resource intensive and affect the environment negatively [4]. The environmental impacts depend on a variety of natural and human-driven processes, including soil degradation, water use and pollution, loss of biodiversity, and climate change.

The choices made regarding food consumption can significantly reduce the impact on the environment. For example, dietary shifts towards reduced meat and dairy consumption can reduce greenhouse gas (GHG) emissions and land use. Adoption of flexitarian, pescatarian, vegetarian, or vegan diet patterns globally would reduce GHG emissions related to diet by $41-74 \%$ [5]. Nevertheless, research shows that habits, familiarity, and beliefs about meat, including consumers' perception that meat is a necessary component of a diet because it has an indispensable nutritional value, may hamper the adoption of plant-based diets [6]. Moreover, in some countries, there is a contradiction between health and environmental guidelines [7]. A study that examined the impact of halving the consumption of meat, dairy products, and eggs in the European Union showed a $40 \%$ reduction in nitrogen emissions, $25-40 \%$ reduction in GHG, and $23 \%$ per capita less use of cropland for food production could be achieved [8]. However, such a change in consumption behavior does not appear to be realistic. The research revealed many underlying reasons for this, including lack of awareness of the association between meat consumption and climate change [9]. According to Poore and Nemecek [10], the effects of the lowest-impact products of animal origin were found to outweigh those of vegetable substitutes, thus confirming the importance of changes in dietary patterns. Chai et al. [11] published a review that highlighted the vegan diet as being optimal for the environment because its production results in the lowest levels of GHG emissions. Nevertheless, it is also possible to obtain similar sustainability indicators even without eliminating meat and dairy products from the diet, provided that these food categories are highly reduced [11].

On the other hand, the consumption of organic foods in response to concerns regarding quality, safety, and environmental impacts of conventional food has increased in recent years [12,13]. However, in almost all European markets there is a disparity between consumers' intentions to buy organic products and the level of actual purchasing. This is explained by high prices, limited availability, lack of trust, or lack of knowledge [14]. Eating seasonal and local food reduces environmental impact significantly less than by reducing consumption of red meat and dairy products, but this behavioral change has been perceived as more acceptable [15]. Moreover, studies show that consumers' choice of seasonal food may be based on the wrong assumption that it is more environmentally beneficial in comparison to purchasing organic food and reducing meat consumption [16].

The benefits of reducing wasted food and packaging include reduced environmental impact over the lifecycle of a product. Various studies reveal that between one-third and one-half of global food production is not consumed. Food waste in the EU is estimated to be 88 million tons per year [17]. Many factors influence food wastage in the final consumption phase, including excessive purchasing, excessive preparation, wrong interpretation of expiry date, and inadequate storage [18]. Although packaging prevents food waste and losses, thus protecting the environment, the current practice of using mostly oil-based packaging materials, designed for single and short use and unable to be recycled, negatively affects the environment [19]. Nevertheless, as many studies show, environmentally friendly packaging is less important to customers than other product characteristics [20].

Making sustainable food choices does not depend only on knowledge, skills, and abilities. There are many other individual, household, and environmental factors involved [21]. Because cultural, culinary, and economic factors related to geographic area shape willingness and possibilities to act pro-environmentally [22], there is a need to assess the situation and develop initiatives that tackle issues at a national level, in addition to the EU level. Therefore, this study aimed to investigate behaviors and attitudes of a Croatian sample concerning the influence of environmental and political determinants on food choices. Many studies have found that various socio-demographic factors are associated with pro-environmental behavior [23]. Consequently, we examined the relationship 
between socio-demographic data and environmental and political determinants of food choices to identify which are facilitators or barriers to change.

\section{Methods}

\subsection{Questionnaire}

The questionnaire was developed as a part of the multinational project entitled "Psycho-social motivations associated with food choices and eating practices (EATMOT)". The design of the questionnaire was described in detail in previous works from the project team [24-26]. The questionnaire included two parts. In the first part, relevant socio-demographic data were collected. Participants indicated their age, gender (female or male), the highest education level (elementary school, high school, higher education), place of residence (rural area, urban area, suburban area), marital status (unmarried, married/cohabitating, divorced, widow/widower), employment status (employed, unemployed, student, retired, student with a job), whether they are responsible for food supplies (yes/no), whether they are following specific eating practices (raw foodism, fruitarianism, vegetarianism, veganism, flexitarianism, caloric restriction, religious restrictions, other, general principles of healthy eating), and whether they are smokers or not (have never smoked, used to smoke, smoker, occasional smoker).

In the second part of the questionnaire, participants filled in the Environmental and Political Motivations Scale of food choice determinants [27]. The original scale was translated into English by the CI\&DETS Research Center of the Polytechnic Institute in Viseu, Portugal. The English version was translated into Croatian by two native speakers of Croatian with experience in public health and nutrition studies. No items were modified or removed or added during the translation. The translated scale was examined by the creators of the English translation, who verified that the overall structure was unchanged. Participants expressed their level of agreement with each of seven items (e.g., It is important to me that the food I eat is prepared/packed in an environmentally friendly way) on a 5-point scale (1—strongly disagree, 5 —strongly agree).

\subsection{Participants}

In total, 1534 participants from different parts of Croatia took part in the survey. The final sample consisted of 1472 participants $\left(M_{\mathrm{age}}=35.83, S D=14.41\right)$, the majority of whom were females $(n=856)$. Participants with missing values on socio-demographic data $(n=46)$, those who did not answer any question on the Environmental and Political Motivation Scale of food choice determinants $(n=2)$, juveniles $(n=5)$, and those with errors during the data coding process $(n=9)$ were excluded from the analyses.

\subsection{Data Collection}

This work is a part of the multinational EATMOT project [26]. The project "EATMOT: Psycho-social motivations associated with food choices and eating practices" was conducted simultaneously in 18 counties: Argentina, Brazil, Croatia, Cyprus, Egypt, Greece, Hungary, Italy, Latvia, Lithuania, Macedonia, Netherlands, Poland, Serbia, Slovenia, Romania, and The United States of America, in addition to the lead country (Portugal). The objective behind the development of this project was to study the different psychic and social motivations that determine people's eating patterns, either concerning their choices or eating habits. The areas explored included factors linked to food choices in these main domains: health motivations, economic factors, emotional aspects, cultural influences, marketing and commercials, and environmental concerns.

The data were collected from November 2017 to March 2018. Because the scope of the project was wider than the scope of the present study, additional data that are not presented here (e.g., data on other food choice determinants) were collected in all participating countries.

Participation in the study was anonymous and voluntary. Before filling in the questionnaire, participants gave informed consent. The study was approved by the Human Research Ethics Committee 
of the General Hospital Zadar (Reg. No. 01-5623-6/1). All data were collected and analyzed following the Declaration of Helsinki. Additionally, the data were handled according to The EU Directive on GDPR - Regulation (EU) 2016/679.

\subsection{Data Analysis}

\subsubsection{Environmental and Political Motivations Scale}

The Environmental and Political Motivations Scale was recently constructed and a small amount of data exists regarding its factor structure. Guiné et al. [26] tested the stability of the assumed one-factor solution in the Portuguese sample using confirmatory factor analysis (CFA). The authors retained a one-factor solution, but only after the exclusion of two items and inclusion of covariance between the residuals of four items. This suggests possible factor structure instability and influence of methodological factors (e.g., item wording) on the scale's structure. Moreover, this study is the first implementation of the scale for a Croatian sample; thus, its factor structure may be different than in the Portuguese sample. For these reasons, we decided to take another analytical approach than that of Guiné et al. [26]. Rather than assuming an a priori factor structure of the scale and checking the validity of the assumption with CFA, exploratory factor analysis (EFA), which does not impose any constraints on the factor structure and is appropriate to use at the initial stage of scale development, was performed. EFA was conducted in JASP (v.0.11.1.0) software using the "MinRes" procedure. Before analysis was conducted, missing values in three items (four values in total) were replaced by the item's medians. In addition, we checked for univariate skewness and kurtosis values, which were in an acceptable range of \pm 1 . To estimate the number of factors, multiple criteria were used: results of Horn's parallel analysis [28], size of factor loadings (greater or equivalent to 0.30 [29], a solution without significant cross-loadings (greater or equivalent to 0.30 ), a solution with at least three items per factor [30], and theoretical interpretability of the solution. Solutions with both orthogonal (without rotation, with varimax rotation) and oblique factors (with oblimin rotation) were tested. However, none of the three extracted factors (based on the results of parallel analysis) was clearly interpretable, regardless of the method of rotation. Most problematic were cross-loadings among factors and behavior of items 2,3, and 6, which were consistently separated from the other items (but were not saturated by the same factor). Removing these items from the analysis had the effect of reducing the initial scale to half, and losing potentially relevant information contained in these items. Factor loadings for extracted solutions are given in Tables A1-A3 (Appendix A).

Based on the results of EFA, because no clear factor structure emerged, the most appropriate approach to test the relationship between socio-demographic data and environmental and political motivators of food choices was to conduct the analyses at the item level. The scale used to measure the individual items was a 5-point Likert scale to measure the level of agreement with the provided sentences, marking them with a score from $1=$ totally disagree to $5=$ totally agree. Some of the items were included in the questionnaire in reverse order, purposely, to measure the level of engagement of the respondents in answering, and thus avoiding a possible tendency to automatically score the items with maximum values.

\subsubsection{Statistical Approach}

All of the analyses were conducted in JASP software. To test differences in group means for environmental and political motivators of food choices in relation to socio-demographic variables with two categories (gender, place of residence, educational level, marital status, employment status, eating practices, and responsibility for food supplies), Welch's $t$-test (which is robust against violation of the equality of variance assumption and unequal group size [31]) was used. Because the number of cases was very high (significantly exceeding 1000), normality of the distribution was assumed [32]. To test group differences concerning the habit of smoking, one-way ANOVA was conducted. The relationship between age and motivators of food choices was analyzed with Pearson's $r$ correlation coefficient 
(values shown in Table A4 in Appendix B). Because analyses were conducted at an item level, meaning that for each socio-demographic variable seven independent analyses were calculated, Bonferroni correction (0.05/number of analysis) was applied to $p$-values to maintain the family-wise type I error rate at $5 \%$. Therefore, in the present case, the result of each conducted analysis was statistically significant if the corresponding $p$-value was $<0.007$ to maintain the type I error under the specified limits.

\section{Results and Discussion}

\subsection{Socio-Demographic Data}

Table 1 presents the sociodemographic characterization of the sample. For socio-demographic variables with more than two categories (highest education level, place of residence, marital status, employment status, eating practices), some categories were underrepresented; thus, to interpret the analyses clearly, and produce more stable results, categories were collapsed. For each variable, two categories were created. Specifically, regarding educational level, participants were divided into groups of those who finished elementary/high school $(n=962)$ and those with higher education $(n=510)$. Based on the place of residence, participants were categorized as rural/suburban $(n=616)$ or urban citizens $(n=856)$. Concerning marital status, participants were treated as married/cohabiting $(n=692)$ or unmarried/divorced/widow/widower $(n=780)$. With respect to employment status, participants were coded as employed/student with a job $(n=903)$ or unemployed/student/retired $(n=569)$. Regarding eating practices, groups of those who practice specific eating practices $(n=270)$ and those who follow general principles of healthy eating $(n=1202)$ were created. Concerning the habit of smoking, categories were not collapsed because there were enough participants in each category and it is questionable whether collapsing some categories (e.g., participants who used to smoke with participants who have never smoked) could be justified. Most of the participants have never smoked $(n=535)$, followed by active smokers $(n=483)$, those who used to smoke $(n=269)$, and occasional smokers $(n=185)$. Finally, regarding responsibility for food supplies, most of the participants were responsible for food purchase $(n=1167)$. The full presentation of the socio-demographic data can be found in Table 1.

\subsection{Descriptive Data}

Descriptive data for environmental and political determinants of food choices on the whole sample of participants are given in Table 2. In general, participants report a neutral rate of agreement with the items, with the exception of items related to food waste and food origin, for which they express a moderate amount of agreement. These data refer to the average of all scores obtained for each of the items, and allow analysis of the trend considering the whole dataset, i.e., the global sample accounting for the Croatian population. Further analysis is shown below of the influence of sociodemographic variables on the environmental and political determinants of food choices.

Overall, these results indicate that environmental and political determinants do not play a significant role in the food choices of the participants. Although a similar survey conducted in Portugal [27] found that environmental and political factors influenced food choices, the results correspond to the findings of other studies conducted in Croatia. A survey published in 2012 showed that the concern for the environment for Croatian citizens was not significant [33]. Among the economy, health care, poverty, crime, education, immigration, and terrorism, the environment was recognized as the most important issue by $2 \%$ of participants. The majority of the respondents (42\%) thought that there were more important things to do than protect the environment. Although largely aware of environmental problems, $65 \%$ of participants were unwilling to reduce living standards for the benefit of the environment. Moreover, Croatia's citizens gave preference for the state to play a crucial role as a control and sanction authority, choosing fines and tax systems as interventions into individual behavior. Although many efforts have been made to implement EU environmental policy and law since joining the EU, many challenges remain, including citizen engagement [34]. Similarly, a recent study found 
that only $3 \%$ of Croatian consumers took into account information on corporate social responsibility when buying food (a dominant factor that influences food purchase decisions was quality (69\%) [35]. Furthermore, most of the participants reported a neutral rate of agreement with the statement that they obtained information about the corporate social responsibility of food producers before purchase.

Table 1. Socio-demographic data ( $\mathrm{N}=1472$ participants).

\begin{tabular}{|c|c|c|c|}
\hline Variable & Group & $\mathbf{N}$ & $\%$ \\
\hline \multirow{2}{*}{ Gender } & Males & 653 & 44.36 \\
\hline & Females & 819 & 55.64 \\
\hline \multirow{3}{*}{ Education } & Elementary school & 78 & 5.30 \\
\hline & High school & 884 & 60.05 \\
\hline & Higher education & 510 & 34.65 \\
\hline \multirow{3}{*}{ Place of residence } & Rural area & 335 & 22.76 \\
\hline & Urban area & 856 & 58.15 \\
\hline & Suburban area & 281 & 19.09 \\
\hline \multirow{4}{*}{ Marital status } & Unmarried & 667 & 45.31 \\
\hline & Married/Cohabiting & 692 & 47.01 \\
\hline & Divorced & 67 & 4.55 \\
\hline & Widow/Widower & 46 & 3.13 \\
\hline \multirow{5}{*}{ Employment status } & Employed & 838 & 56.93 \\
\hline & Unemployed & 168 & 11.41 \\
\hline & Student & 273 & 18.55 \\
\hline & Retired & 128 & 8.70 \\
\hline & Student with a job & 65 & 4.42 \\
\hline \multirow{2}{*}{$\begin{array}{l}\text { Responsible for food } \\
\text { supply }\end{array}$} & Yes & 1167 & 79.28 \\
\hline & No & 305 & 20.72 \\
\hline \multirow{9}{*}{ Specific eating practices } & Raw foodism & 7 & 0.48 \\
\hline & Frutarianism & 11 & 0.75 \\
\hline & Vegetarianism & 23 & 1.56 \\
\hline & Veganism & 3 & 0.20 \\
\hline & Flexitarianism & 86 & 5.84 \\
\hline & Caloric restriction & 76 & 5.16 \\
\hline & Religion restrictions & 41 & 2.79 \\
\hline & Other & 23 & 1.56 \\
\hline & Following principles of healthy eating & 1202 & 81.66 \\
\hline \multirow{4}{*}{ Habit of smoking } & Have never smoked & 535 & 36.35 \\
\hline & Used to smoke & 269 & 18.27 \\
\hline & Active smoker & 483 & 32.81 \\
\hline & Occasional smoker & 185 & 12.57 \\
\hline
\end{tabular}

Table 2. Descriptive data on the whole sample (measuring scale from 1—strongly disagree to 5 - strongly agree).

\begin{tabular}{|c|c|c|}
\hline Item & Mean & Standard Deviation \\
\hline $\begin{array}{l}\text { 1. It is important to me that the food I eat is prepared/packed in an } \\
\text { environmentally friendly way }\end{array}$ & 3.16 & 1.06 \\
\hline 2. When I cook I have in mind the quantities to avoid food waste & 3.84 & 0.99 \\
\hline 3. It is important to me that the food I eat comes from my own country & 3.53 & 1.10 \\
\hline $\begin{array}{l}\text { 4. I prefer to eat food that has been produced in a way that animals' } \\
\text { rights have been respected }\end{array}$ & 3.01 & 1.07 \\
\hline $\begin{array}{l}\text { 5. I choose foods that have been produced in countries where human } \\
\text { rights are not violated }\end{array}$ & 2.90 & 1.06 \\
\hline $\begin{array}{l}\text { 6. I avoid going to restaurants that do not have a recovery policy of } \\
\text { food surplus }\end{array}$ & 2.62 & 1.04 \\
\hline $\begin{array}{l}\text { 7. I prefer to buy foods that comply with policies of minimal usage } \\
\text { of packaging }\end{array}$ & 2.86 & 1.06 \\
\hline
\end{tabular}


These results suggest that avoiding food waste by taking care of quantities during cooking and eating domestic food are more important to the participants in comparison to other examined behaviors and attitudes (Table 2). However, further research is needed to examine which factors shape an observed attitude and behavior. Namely, it is possible that the intent to avoid food waste and the importance of eating food produced in Croatia observed in this study are related to motives other than protecting the environment, such as saving money or social concerns. Complex consumer behaviors (planning, purchase, storage, and cooking) influence food waste, reasons may be personal or product-specific, and motives for reducing food waste are various [36]. For example, a survey performed as a part of the Waste \& Resources Action Program in the United Kingdom revealed that the most motivating factor was the possibility of saving money, followed by efficient home management, feelings of guilt, eating the healthiest diet possible, reducing the impact on the environment, and food shortages in other countries [37]. According to a study exploring food waste drivers in Croatian households, the majority of participants considered food waste a financial loss [18]. Many studies indicate that poorer households waste less and the 2013 Flash Eurobarometer survey revealed that a lower percentage of food waste occurs in countries with a lower income per capita [36]. Because Croatia is among the poorest countries in the EU [38], it is possible that avoiding food waste is mainly motivated by saving money. This assumption, that the main motive for avoiding food waste is not the protection of the environment, is also based on the result that shows the low importance of avoiding food waste in restaurants (Table 2).

Consumer ethnocentrism, corresponding to the preference for domestic products over imports, is related to various affected, cognitive, and behavioral reactions [39]. Political and economic factors are often more important than environmental. Therefore, commercial or state-led "buy domestic" campaigns often mention protecting domestic jobs and the national economy, not environmental protection [40]. Correspondingly, the "Let's Buy Croatian" campaign led by the Croatian Chamber of Economy calls for promotion and development of a prosperous and competitive Croatian economy and highlights the importance of saving jobs [41]. Results of the Croatian study published in 2012 indicate that participants preferred domestic products, but motives were not investigated [42].

\subsection{The Relationship between Socio-Demographic Data and Environmental and Political Determinants of Food Choices}

An overview of research on determinants of pro-environmental behavior reveals that the impact of socio-demographic factors is not consistent, as expected considering the wide range of environmental problems; differences in time, money, and magnitude of lifestyle changes needed to adopt a certain behavior; and a multitude of other, interdependent factors [43]. Therefore, because the questionnaire covers various aspects related to food choices, it is in accordance with the expectations that socio-demographic factors have different impacts (Table 3).

Socio-demographic factors that influence food choices in this study are age (Table A4, Appendix B), gender (Table A5, Appendix C), education level (Table A6, Appendix C), marital status (Table A7, Appendix C), responsibility for food supply (Table A8, Appendix C), eating practices (Table A9, Appendix C), and smoking (Table A10, Appendix C). These results show that there are no statistically significant differences in environmental and political determinants of food choices based on the place of residence (Table A11, Appendix C) and employment status (Table A12, Appendix C).

The age of the participants positively impacts avoiding food waste and eating domestic food: with the increase in age, participants try more to avoid excessive food waste and have a higher preference for domestic products. However, these effects are small in size. The amount of explained variance dependent on age is $2.6 \%$ for the avoidance of excessive food waste (value of correlation is 0.16 ) and $5.3 \%$ for preference for domestic products (correlation is equal to 0.23) (Table A4, Appendix B). The observation that older people waste less food is in accordance with several recent studies. For example, a study about food waste at the household level in the Netherlands revealed that increasing age had a diminishing impact [44]. Furthermore, according to the ANIBES study, household 
plate waste generated by Spanish consumers [45] and the amount of food waste (mostly generated by cooking excessive amounts) in Hungarian households decreases with age [46]. In contrast, in some studies age did not have significant influence [47,48]. Moreover, a study on food waste in households in the Czech Republic showed that the people who waste food the most were those older than 65 years [49]. The explanation for these observed differences may be that different causes of food waste (e.g., impulse buying, lack of planning, understanding of date labels, and knowledge of proper storage practices) are affected differently by age. The finding that older participants have higher levels of ethnocentric tendencies is in line with the dominant results found in the literature [50].

Table 3. Descriptive data as average scores for the items about sustainable food choices according to sociodemographic variables.

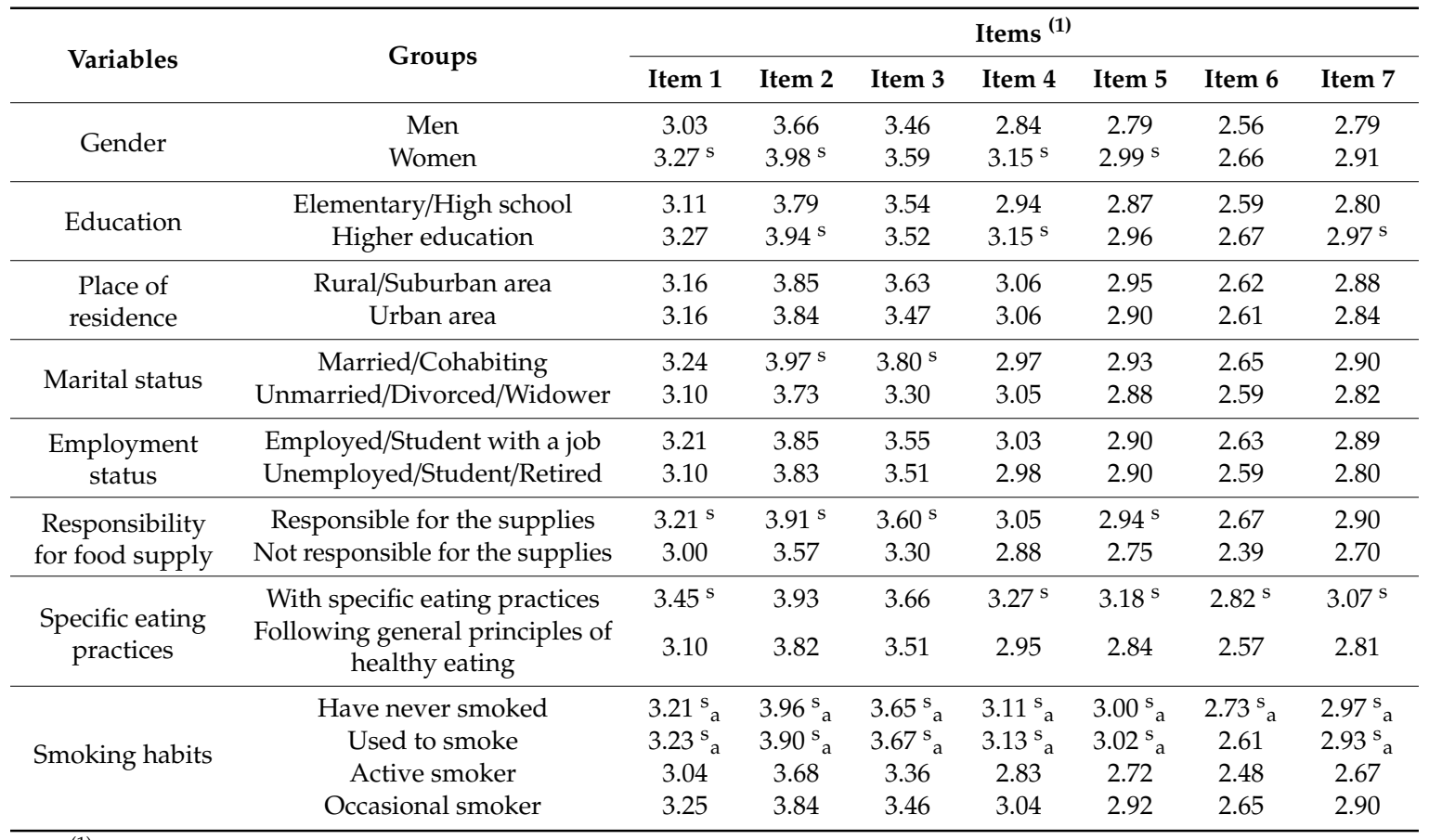

(1) Full description of items: 1. It is important to me that the food I eat is prepared/packed in an environmentally friendly way; 2 . When I cook I have in mind the quantities to avoid food waste; 3 . It is important to me that the food I eat comes from my own country; 4 . I prefer to eat food that has been produced in a way that animals' rights have been respected; 5 . I choose foods that have been produced in countries where human rights are not violated; 6. I avoid going to restaurants that do not have a recovery policy of food surplus; 7 . I prefer to buy foods that comply with policies of minimal usage of packaging. ${ }^{s}$ The mean is significantly higher in comparison to the mean of the other classes of the same sociodemographic variable. For details, see Appendix C (Tables A5-A9). ${ }^{\mathrm{s}}$ a The mean is significantly higher than the mean of active smokers. For details, see Appendix C (Table A10).

There are different findings in the literature regarding the role of gender on pro-environmental behavior. This effect depends on environmental issues and whether attitudes, knowledge, concern, or behavior are investigated [43]. In this study, women score more highly on items regarding food preparation/packaging, food waste, and respect of animal and human rights, indicating they put more weight on these specific environmental and political determinants of food choice than men (Table A5, Appendix C). However, it should be noted that the average difference in scores is low (around 0.2 points on a 5-point scale), which suggests that gender differences are not substantial. Nonetheless, significant differences were found between genders for most items, with the exception of the item about food waste at restaurants. In general, both men and women gave neutral answers (average score on most items is around the neutral point of 3), with the exception of items concerning food waste and food origin. On these items, participants tend to agree to some extent with the item's content (with women agreeing more than men). 
Many studies suggest that women are more concerned about the environment than men [43,51,52]. Women's roles as caregivers and nurturers [52] have been related to stronger environmental concern. However, it appears that in modern households this difference diminishes or disappears because gender roles are more blurred [51]. The results suggest that women also tend to be more concerned about animal welfare in accordance with many studies revealing that women show higher levels of positive behaviors and attitudes toward animals (see, e.g., in [53-56]). Various explanations have been offered, including hormonal and genetic differences, and women's social role and structural location in society [57]. Similarly, studies show that women are more likely to buy or boycott products in accordance with their ethical, environmental, and political values, and their role as caregivers has been offered as an explanation [58]. Regarding food waste, according to the literature, gender has different influences on practices. Some studies found that men are prone to wasting more food than women [36,59-61], others stated that gender had no significant influence [44,46,47,49], whereas some studies revealed that women wasted more food than men [48,62]. It seems that there is a conflict between good-provider identity or a "good mother" behavior and awareness of the negative consequences of wasting food [63]. A recent study performed in Romania found that the effect of gender on food attitudes and behaviors was different depending on age group, probably reflecting the fact that the role of women changes with age [64].

We found that participants with a higher education tend to avoid food waste and excessive packaging, and are more concerned about animal welfare, in comparison to participants who finished elementary or high school (Appendix C). However, educational differences are not strongly pronounced because the average difference between participants from the two groups is around 0.2 points (Table A6, Appendix C). Similar to the findings concerning gender differences, participants from both categories tend to give neutral answers, with the exception of items regarding food waste and food origin. Many studies show that people with higher education are more aware and interested in, and possess a better knowledge of, environmental issues [43]. However, some studies revealed that there is a gap between the possession of knowledge and awareness and certain behaviors [43]. The effect of education, in which participants with higher education show a more positive attitude towards animal welfare, is in agreement with other studies [55,65-67]. Similarly, packaging material reduction has been recognized as a method to reduce environmental impact by environmentally conscious people, particularly those with higher education [68]. Regarding food waste, literature data are not consistent. A higher level of education did not influence food wasted in Finnish [48], Philippine [47], and Dutch households [44]. A study of EU-27 individuals' food waste behavior published in 2015 found that people with higher education tend to throw away a larger amount of food [36]. Similar results were obtained in recent studies performed in Poland [61] and Hungary [46]. On the contrary, according to recent studies, people with a university degree wasted food less often in Czech [49], Egypt [69], and Lebanon [70].

Regarding marital status, significant differences were found for items 1 to 3 (environmentally friendly foods, avoid waste at home, and preference for domestic products), with married people or cohabiting showing higher accordance with the items' contents. This finding that participants who are married or cohabitating care more about reducing food waste in comparison to those without a life partner (Table A7, Appendix C) is in agreement with a study showing that, as the number of Croatian household members increases, the amount of food waste decreases [18].

Participants who are responsible for food supply agree more with the content of most of the items. The exemption is an item dealing with respect of animal rights, for which a statistically significant difference in the rate of agreement is not present (Table A8, Appendix C). Differences between the two groups of participants are not strongly pronounced (the average difference is around 0.2 points; Table A8). In general, participants from both groups gave neutral answers, with the exception of items concerning food waste (participants from both groups tend to agree to some extent with the item's content), food origin (in particular, participants responsible for food supply tend to agree to 
some extent with the item's content), and restaurants' recovery policy of food surplus (in particular, participants who are not responsible for the supplies tend to agree less with the item's content).

Participants who follow specific eating practices agree more with the content of most of the items (Table A9, Appendix C). Exceptions are items related to food waste and food origin, for which a statistically significant difference in the rate of agreement is not present. Differences between the two groups of participants are not strongly pronounced (the average difference is around 0.3 points; Table A9). For most of the items, participants gave neutral answers, with the exception of items dealing with food waste and food origin, for which participants from both groups gave answers that were not neutral. In this sample, following specific eating practices mostly means following plant-based diets, and therefore it could be expected that those participants express more concern about the environment and animal welfare. Research shows that, in addition to health, the most commonly reported motives for a plant-based diet are lowering the environmental impact and respecting animal rights [6,71,72].

The obtained results indicate that smoking is negatively associated with examined pro-environmental attitudes and behaviors. Results of the one-way ANOVA (Table A10, Appendix C) reveal statistically significant differences among groups of participants on all items, with the exception of the item related to food preparation/packing. To determine the groups for which differences are present, post hoc group comparison with Tukey's test was performed. On all of the items (2-7), participants who have never smoked score higher than active smokers (all $p<0.01$ ), but do not differ on any item from the participants who used to smoke and occasional smokers (all $p>0.05$ ). Furthermore, participants who used to smoke, on all items (except the item asking about restaurants' recovery policy of food surplus) score higher than active smokers (all $p<0.01$ ), but are not statistically different from occasional smokers (all $p>0.05$ ). Finally, active smokers do not differ in scores in comparison to occasional smokers (all $p>0.05$ ). All of the differences are not strongly pronounced (around 0.3 points; Table A10). Recent studies indicate that wellbeing and life satisfaction positively affect pro-environmental behavior [73]. Furthermore, smoking behavior has been associated with psychosocial stress [74], and sustainable food consumption behavior is often related to a healthy lifestyle [75].

\subsection{Limitations of the Study}

Although the present study provided highly relevant information about the shaping of behaviors by Croatian consumers towards more sustainable options, and the number of participants was expressive, we must highlight that it has certain limitations, which should be considered when extrapolating the data. This study used a convenience sample, which may not accurately represent all of the sectors of the Croatian population, particularly regarding elderly people. The market for environmentally friendly products is growing globally in all sectors, leading to changes in the behavior, attitudes, and knowledge of consumers. Therefore, the results obtained in this study may differ from those from another sample, or another time, because consumers simultaneously study, direct, and dictate marketing towards their own needs and desires. Furthermore, it is important to note that we did not observe the behavior of participants directly and it is possible that pro-environmental attitudes and intentions do not translate into pro-environmental action. In addition, it is possible that people with more knowledge or interest who completed the survey gave what they thought were desirable answers, which could lead to overestimation in the results. However, despite its limitations, we believe that this study provides some valuable insights and can be seen as laying the groundwork for future research.

\section{Conclusions}

The findings from the present study indicate that environmental and political determinants do not play a significant role in the food choices of a sample of the Croatian population. Age, gender, education level, marital status, responsibility for food supply, eating practices, and smoking affect the participants' concerns with environmental and political determinants, but differences are not 
strongly pronounced. Regardless of socio-demographic characteristics, the participants mostly report a neutral rate of agreement with the offered statements. Results show that the place of residence and employment status do not affect Croatians' food choices towards sustainability. However, gender differences indicate that women have greater concerns about sustainability, and therefore their food choices are shaped according to environmental factors to minimize their impact. In addition, education plays an important role because people with a higher education level also revealed greater concerns about the environment, and their food choices are more affected by environmental issues. Additionally, people who live with companions and those who are responsible for the food supply also presented a higher concern towards environmental drivers of food choices.

In addition to group differences, the overall results indicated that food choices of Croatians continue to be only slightly influenced by environmental factors. This is a concern because it is critical to better adapt food supply chains, including the role of consumers, to help meet the goals of sustainable global development, as highlighted by the United Nations.

Based on the present study, it appears there is the need for urgent environmental interventions and activism in Croatia. Development and implementation of educational programs to emphasize the importance of the environment, and the potential of sustainable food choices to preserve it, may contribute to the adoption of more pro-environmental behavior. To determine the scope, target audience, and content of such programs, it is necessary to examine facilitators and barriers to environmentally friendly eating. Further research should address these issues in more detail. A partnership between various stakeholders (e.g., companies, educational institutions, governmental bodies, and non-governmental organizations) could be effective in promoting and fostering behavioral choices that reduce harm to the environment by various types of activities.

Author Contributions: Conceptualization, J.Č. and M.M.S.; methodology K.J.; software K.J.; validation R.P.F.G.; formal analysis K.J.; investigation M.M.S.; data curation M.M.S.; writing—original draft J.Č.; writing—review and editing K.J., M.M.S. and R.P.F.G.; visualization J.Č., K.J. and M.M.S.; supervision R.P.F.G.; project administration R.P.F.G. All authors have read and agreed to the published version of the manuscript.

Funding: This research received no external funding.

Acknowledgments: The authors wish to thank all participants involved in the study. This work was prepared in the ambit of the multinational project EATMOT from CI\&DETS Research Centre (Polytechnic Institute of Viseu, Portugal) with reference PROJ/CI\&DETS/CGD/0012.

Conflicts of Interest: The authors declare no conflict of interest.

\section{Appendix A. Factor Loadings for EFA}

Table A1. Factor loadings of Environmental and Political Motivations Scale of food choice determinant items under the assumption of factor orthogonality and with no rotation applied.

\begin{tabular}{|c|c|c|c|}
\hline Item & Factor 1 & Factor 2 & Factor 3 \\
\hline $\begin{array}{l}\text { 1. It is important to me that the food I eat is prepared/packed in an } \\
\text { environmentally friendly way }\end{array}$ & 0.61 & 0.20 & -0.05 \\
\hline 2. When I cook I have in mind the quantities to avoid food waste & 0.36 & 0.34 & 0.30 \\
\hline 3. It is important to me that the food I eat comes from my own country & 0.39 & 0.28 & 0.28 \\
\hline $\begin{array}{l}\text { 4. I prefer to eat food that has been produced in a way that animals' } \\
\text { rights have been respected }\end{array}$ & 0.73 & 0.11 & -0.31 \\
\hline $\begin{array}{l}\text { 5. I choose foods that have been produced in countries where human } \\
\text { rights are not violated }\end{array}$ & 0.79 & 0.00 & -0.24 \\
\hline $\begin{array}{l}\text { 6. I avoid going to restaurants that do not have a recovery policy of } \\
\text { food surplus }\end{array}$ & 0.82 & -0.49 & 0.28 \\
\hline $\begin{array}{l}\text { 7. I prefer to buy foods that comply with policies of minimal usage } \\
\text { of packaging }\end{array}$ & 0.75 & 0.00 & 0.00 \\
\hline
\end{tabular}


Table A2. Factor loadings of Environmental and Political Motivations Scale of food choice determinant items under the assumption of factor orthogonality and with varimax rotation applied.

\begin{tabular}{|c|c|c|c|}
\hline Item & Factor 1 & Factor 2 & Factor 3 \\
\hline $\begin{array}{l}\text { 1. It is important to me that the food I eat is prepared/packed in an } \\
\text { environmentally friendly way }\end{array}$ & 0.53 & 0.15 & 0.35 \\
\hline 2. When I cook I have in mind the quantities to avoid food waste & 0.13 & 0.07 & 0.56 \\
\hline 3. It is important to me that the food I eat comes from my own country & 0.16 & 0.12 & 0.52 \\
\hline $\begin{array}{l}\text { 4. I prefer to eat food that has been produced in a way that animals' } \\
\text { rights have been respected }\end{array}$ & 0.76 & 0.17 & 0.17 \\
\hline $\begin{array}{l}\text { 5. I choose foods that have been produced in countries where human } \\
\text { rights are not violated }\end{array}$ & 0.74 & 0.31 & 0.16 \\
\hline $\begin{array}{l}\text { 6. I avoid going to restaurants that do not have a recovery policy of } \\
\text { food surplus }\end{array}$ & 0.36 & 0.91 & 0.18 \\
\hline $\begin{array}{l}\text { 7. I prefer to buy foods that comply with policies of minimal usage } \\
\text { of packaging }\end{array}$ & 0.55 & 0.41 & 0.28 \\
\hline
\end{tabular}

Table A3. Factor loadings of Environmental and Political Motivations Scale of food choice determinant items under the assumption of oblique factors and with oblimin rotation applied.

\begin{tabular}{|c|c|c|c|}
\hline Item & Factor 1 & Factor 2 & Factor 3 \\
\hline $\begin{array}{l}\text { 1. It is important to me that the food I eat is prepared/packed in an } \\
\text { environmentally friendly way }\end{array}$ & 0.51 & -0.03 & 0.25 \\
\hline 2. When I cook I have in mind the quantities to avoid food waste & -0.02 & -0.01 & 0.59 \\
\hline 3. It is important to me that the food I eat comes from my own country & 0.00 & 0.04 & 0.53 \\
\hline $\begin{array}{l}\text { 4. I prefer to eat food that has been produced in a way that animals' } \\
\text { rights have been respected }\end{array}$ & 0.85 & -0.07 & -0.01 \\
\hline $\begin{array}{l}\text { 5. I choose foods that have been produced in countries where human } \\
\text { rights are not violated }\end{array}$ & 0.76 & 0.12 & -0.04 \\
\hline $\begin{array}{l}\text { 6. I avoid going to restaurants that do not have a recovery policy of } \\
\text { food surplus }\end{array}$ & 0.00 & 0.99 & 0.00 \\
\hline $\begin{array}{l}\text { 7. I prefer to buy foods that comply with policies of minimal usage } \\
\text { of packaging }\end{array}$ & 0.45 & 0.29 & 0.13 \\
\hline
\end{tabular}

\section{Appendix B. Correlations between the Age and the Studied Determinants of Food Choices}

Table A4. Correlations between age and environmental and political determinants of food choices.

\begin{tabular}{cc}
\hline Item & Correlation with Age \\
\hline 1. It is important to me that the food I eat is prepared/packed in an environmentally & 0.02 \\
friendly way & $0.16^{* *}$ \\
2. When I cook I have in mind the quantities to avoid food waste & $0.23^{* *}$ \\
4. I is important to me that the food I eat comes from my own country & $-0.08^{*}$ \\
been respected & 0.00 \\
5. I choose foods that have been produced in countries where human rights are not violated & 0.04 \\
6. I avoid going to restaurants that do not have a recovery policy of food surplus & 0.06 \\
7. I prefer to buy foods that comply with policies of minimal usage of packaging & \\
\hline
\end{tabular}




\section{Appendix C. Differences in the Studied Determinants of Food Choices According to Sociodemographic Variables}

Table A5. Gender differences in environmental and political determinants of food choices.

\begin{tabular}{|c|c|c|c|c|c|}
\hline \multirow[b]{2}{*}{ Item } & \multicolumn{3}{|c|}{$M(S D)^{1}$} & \multirow[b]{2}{*}{$d f^{3}$} & \multirow[b]{2}{*}{$p^{4}$} \\
\hline & Men & Women & $t^{2}$ & & \\
\hline $\begin{array}{l}\text { 1. It is important to me that the food I eat is prepared/packed in an } \\
\text { environmentally friendly way }\end{array}$ & $\begin{array}{c}3.03 \\
(1.04)\end{array}$ & $\begin{array}{c}3.27 \\
(1.07)\end{array}$ & 4.48 & 1414.275 & 0.000 * \\
\hline 2. When I cook I have in mind the quantities to avoid food waste & $\begin{array}{c}3.66 \\
(1.04)\end{array}$ & $\begin{array}{c}3.98 \\
(0.92)\end{array}$ & 6.14 & 1315.401 & $0.000 *$ \\
\hline $\begin{array}{l}\text { 3. It is important to me that the food I eat comes from my } \\
\text { own country }\end{array}$ & $\begin{array}{c}3.46 \\
(1.10)\end{array}$ & $\begin{array}{c}3.59 \\
(1.10)\end{array}$ & 2.23 & 1395.558 & 0.026 \\
\hline $\begin{array}{l}\text { 4. I prefer to eat food that has been produced in a way that animals' } \\
\text { rights have been respected }\end{array}$ & $\begin{array}{c}2.84 \\
(1.04)\end{array}$ & $\begin{array}{c}3.15 \\
(1.08)\end{array}$ & 5.55 & 1419.519 & $0.000 *$ \\
\hline $\begin{array}{l}\text { 5. I choose foods that have been produced in countries where } \\
\text { human rights are not violated }\end{array}$ & $\begin{array}{c}2.79 \\
(1.04)\end{array}$ & $\begin{array}{c}2.99 \\
(1.06)\end{array}$ & 3.56 & 1410.318 & $0.000 *$ \\
\hline $\begin{array}{l}\text { 6. I avoid going to restaurants that do not have a recovery policy of } \\
\text { food surplus }\end{array}$ & $\begin{array}{c}2.56 \\
(1.00)\end{array}$ & $\begin{array}{c}2.66 \\
(1.06)\end{array}$ & 1.81 & 1429.920 & 0.070 \\
\hline $\begin{array}{l}\text { 7. I prefer to buy foods that comply with policies of minimal usage } \\
\text { of packaging }\end{array}$ & $\begin{array}{c}2.79 \\
(1.00)\end{array}$ & $\begin{array}{c}2.91 \\
(1.10)\end{array}$ & 2.13 & 1442.744 & 0.034 \\
\hline
\end{tabular}

${ }^{1}$ Mean value (standard deviation); ${ }^{2}$ Test statistic—Welch's $t$-test; ${ }^{3}$ Degrees of freedom; ${ }^{4}$ Significance ${ }^{*} p<0.05$.

Table A6. Educational differences in environmental and political determinants of food choices.

\begin{tabular}{|c|c|c|c|c|c|}
\hline \multicolumn{6}{|c|}{$M(S D)^{1}$} \\
\hline Item & $\begin{array}{l}\text { Elementary/High } \\
\text { School }\end{array}$ & $\begin{array}{l}\text { Higher } \\
\text { Education }\end{array}$ & $t^{2}$ & $d f^{3}$ & $p^{4}$ \\
\hline $\begin{array}{l}\text { 1. It is important to me that the food I eat is } \\
\text { prepared/packed in an environmentally } \\
\text { friendly way }\end{array}$ & $3.11(1.07)$ & $3.27(1.03)$ & 2.72 & 1075.891 & 0.007 \\
\hline $\begin{array}{l}\text { 2. When I cook I have in mind the } \\
\text { quantities to avoid food waste }\end{array}$ & 3.79 (1.01) & $3.94(0.93)$ & 2.88 & 1116.989 & 0.004 * \\
\hline $\begin{array}{l}\text { 3. It is important to me that the food I eat } \\
\text { comes from my own country }\end{array}$ & 3.54 (1.11) & $3.52(1.08)$ & 0.42 & 1063.593 & 0.676 \\
\hline $\begin{array}{l}\text { 4. I prefer to eat food that has been } \\
\text { produced in a way that animals' rights } \\
\text { have been respected }\end{array}$ & $2.94(1.08)$ & $3.15(1.05)$ & 3.70 & 1067.842 & $0.000^{*}$ \\
\hline $\begin{array}{l}\text { 5. I choose foods that have been produced } \\
\text { in countries where human rights are } \\
\text { not violated }\end{array}$ & $2.87(1.06)$ & $2.96(1.05)$ & 1.55 & 1038.540 & 0.121 \\
\hline $\begin{array}{l}\text { 6. I avoid going to restaurants that do not } \\
\text { have a recovery policy of food surplus }\end{array}$ & $2.59(1.07)$ & $2.67(0.98)$ & 1.38 & 1119.125 & 0.166 \\
\hline $\begin{array}{l}\text { 7. I prefer to buy foods that comply with } \\
\text { policies of minimal usage of packaging }\end{array}$ & $2.80(1.09)$ & $2.97(1.00)$ & 2.96 & 1109.835 & 0.003 * \\
\hline
\end{tabular}


Table A7. Marital status differences in environmental and political determinants of food choices.

\begin{tabular}{|c|c|c|c|c|c|}
\hline \multicolumn{6}{|c|}{$M(S D)^{1}$} \\
\hline Item & Married/Cohabiting & $\begin{array}{l}\text { Unmarried/Divorced/ } \\
\text { Widow/Widower }\end{array}$ & $t^{2}$ & $d f^{3}$ & $p^{4}$ \\
\hline $\begin{array}{l}\text { 1. It is important to me that the } \\
\text { food I eat is prepared/packed in } \\
\text { an environmentally friendly way }\end{array}$ & $3.24(1.08)$ & $3.10(1.04)$ & 2.47 & 1436.643 & 0.013 \\
\hline $\begin{array}{l}\text { 2. When I cook I have in mind the } \\
\text { quantities to avoid food waste }\end{array}$ & $3.97(0.92)$ & $3.73(1.03)$ & 4.80 & 1469.982 & 0.000 * \\
\hline $\begin{array}{l}\text { 3. It is important to me that the } \\
\text { food I eat comes from my } \\
\text { own country }\end{array}$ & $3.80(1.00)$ & $3.30(1.13)$ & 9.00 & 1469.825 & 0.000 * \\
\hline $\begin{array}{l}\text { 4. I prefer to eat food that has been } \\
\text { produced in a way that animals' } \\
\text { rights have been respected }\end{array}$ & $2.97(1.05)$ & $3.05(1.10)$ & 1.49 & 1461.491 & 0.137 \\
\hline $\begin{array}{l}\text { 5. I choose foods that have been } \\
\text { produced in countries where } \\
\text { human rights are not violated }\end{array}$ & $2.93(1.07)$ & $2.88(1.04)$ & 1.02 & 1436.767 & 0.307 \\
\hline $\begin{array}{l}\text { 6. I avoid going to restaurants that } \\
\text { do not have a recovery policy of } \\
\text { food surplus }\end{array}$ & $2.65(1.03)$ & $2.59(1.04)$ & 1.09 & 1451.437 & 0.277 \\
\hline $\begin{array}{l}\text { 7. I prefer to buy foods that } \\
\text { comply with policies of minimal } \\
\text { usage of packaging }\end{array}$ & $2.90(1.04)$ & $2.82(1.08)$ & 1.49 & 1459.985 & 0.137 \\
\hline
\end{tabular}

${ }^{1}$ Mean value (standard deviation); ${ }^{2}$ Test statistic—Welch's $t$-test; ${ }^{3}$ Degrees of freedom; ${ }^{4}$ Significance $* x<0.05$.

Table A8. Differences in environmental and political determinants of food choices in regard to responsibility for food supply.

\begin{tabular}{|c|c|c|c|c|c|}
\hline \multicolumn{6}{|c|}{$M(S D)^{1}$} \\
\hline Item & $\begin{array}{l}\text { Responsible for } \\
\text { the Supplies }\end{array}$ & $\begin{array}{l}\text { Is not } \\
\text { Responsible for } \\
\text { the Supplies }\end{array}$ & $t^{2}$ & $d f^{3}$ & $p^{4}$ \\
\hline $\begin{array}{l}\text { 1. It is important to me that the food I eat is } \\
\text { prepared/packed in an environmentally } \\
\text { friendly way }\end{array}$ & $3.21(1.06)$ & $3.00(1.04)$ & 3.00 & 482.097 & $0.003 *$ \\
\hline $\begin{array}{l}\text { 2. When I cook I have in mind the } \\
\text { quantities to avoid food waste }\end{array}$ & $3.91(0.97)$ & $3.57(1.01)$ & 5.34 & 460.962 & $0.000 *$ \\
\hline $\begin{array}{l}\text { 3. It is important to me that the food I eat } \\
\text { comes from my own country }\end{array}$ & $3.60(1.08)$ & $3.30(1.14)$ & 4.17 & 459.104 & $0.000 *$ \\
\hline $\begin{array}{l}\text { 4. I prefer to eat food that has been } \\
\text { produced in a way that animals' rights } \\
\text { have been respected }\end{array}$ & $3.05(1.08)$ & $2.88(1.06)$ & 2.37 & 479.204 & 0.018 \\
\hline $\begin{array}{l}\text { 5. I choose foods that have been produced } \\
\text { in countries where human rights are } \\
\text { not violated }\end{array}$ & $2.94(1.05)$ & $2.75(1.05)$ & 2.83 & 476.454 & $0.005^{*}$ \\
\hline $\begin{array}{l}\text { 6. I avoid going to restaurants that do not } \\
\text { have a recovery policy of food surplus }\end{array}$ & $2.67(1.04)$ & $2.39(1.00)$ & 4.36 & 486.382 & $0.000 *$ \\
\hline $\begin{array}{l}\text { 7. I prefer to buy foods that comply with } \\
\text { policies of minimal usage of packaging }\end{array}$ & $2.90(1.06)$ & 2.70 (1.07) & 2.89 & 471.462 & $0.004^{*}$ \\
\hline
\end{tabular}


Table A9. Differences in environmental and political determinants of food choices in respect to specific eating practices.

\begin{tabular}{|c|c|c|c|c|c|}
\hline \multicolumn{6}{|c|}{$M(S D)^{1}$} \\
\hline Item & $\begin{array}{l}\text { With Specific } \\
\text { Eating Practices }\end{array}$ & $\begin{array}{c}\text { Following } \\
\text { General Principles } \\
\text { of Healthy Eating }\end{array}$ & $t^{2}$ & $d f^{3}$ & $p^{4}$ \\
\hline $\begin{array}{l}\text { 1. It is important to me that the food I eat is } \\
\text { prepared/packed in an environmentally } \\
\text { friendly way }\end{array}$ & $3.45(1.03)$ & $3.10(1.05)$ & 5.07 & 404.676 & 0.000 * \\
\hline $\begin{array}{l}\text { 2. When I cook I have in mind the } \\
\text { quantities to avoid food waste }\end{array}$ & $3.93(0.94)$ & $3.82(1.00)$ & 1.70 & 415.066 & 0.09 \\
\hline $\begin{array}{l}\text { 3. It is important to me that the food I eat } \\
\text { comes from my own country }\end{array}$ & $3.66(1.11)$ & $3.51(1.10)$ & 2.13 & 397.094 & 0.03 \\
\hline $\begin{array}{l}\text { 4. I prefer to eat food that has been } \\
\text { produced in a way that animals' rights } \\
\text { have been respected }\end{array}$ & $3.27(1.10)$ & $2.95(1.06)$ & 4.39 & 389.991 & 0.000 * \\
\hline $\begin{array}{l}\text { 5. I choose foods that have been produced } \\
\text { in countries where human rights are } \\
\text { not violated }\end{array}$ & $3.18(1.06)$ & $2.84(1.05)$ & 4.82 & 396.057 & 0.000 * \\
\hline $\begin{array}{l}\text { 6. I avoid going to restaurants that do not } \\
\text { have a recovery policy of food surplus }\end{array}$ & $2.82(1.31)$ & $2.57(1.00)$ & 3.34 & 370.598 & 0.000 * \\
\hline $\begin{array}{l}\text { 7. I prefer to buy foods that comply with } \\
\text { policies of minimal usage of packaging }\end{array}$ & 3.07 (1.09) & $2.81(1.05)$ & 3.61 & 388.742 & 0.000 * \\
\hline
\end{tabular}

${ }^{1}$ Mean value (standard deviation); ${ }^{2}$ Test statistic—Welch's $t$-test; ${ }^{3}$ Degrees of freedom; ${ }^{4}$ Significance. ${ }^{*} p<0.05$.

Table A10. Differences in environmental and political determinants of food choices in regard to smoking habits.

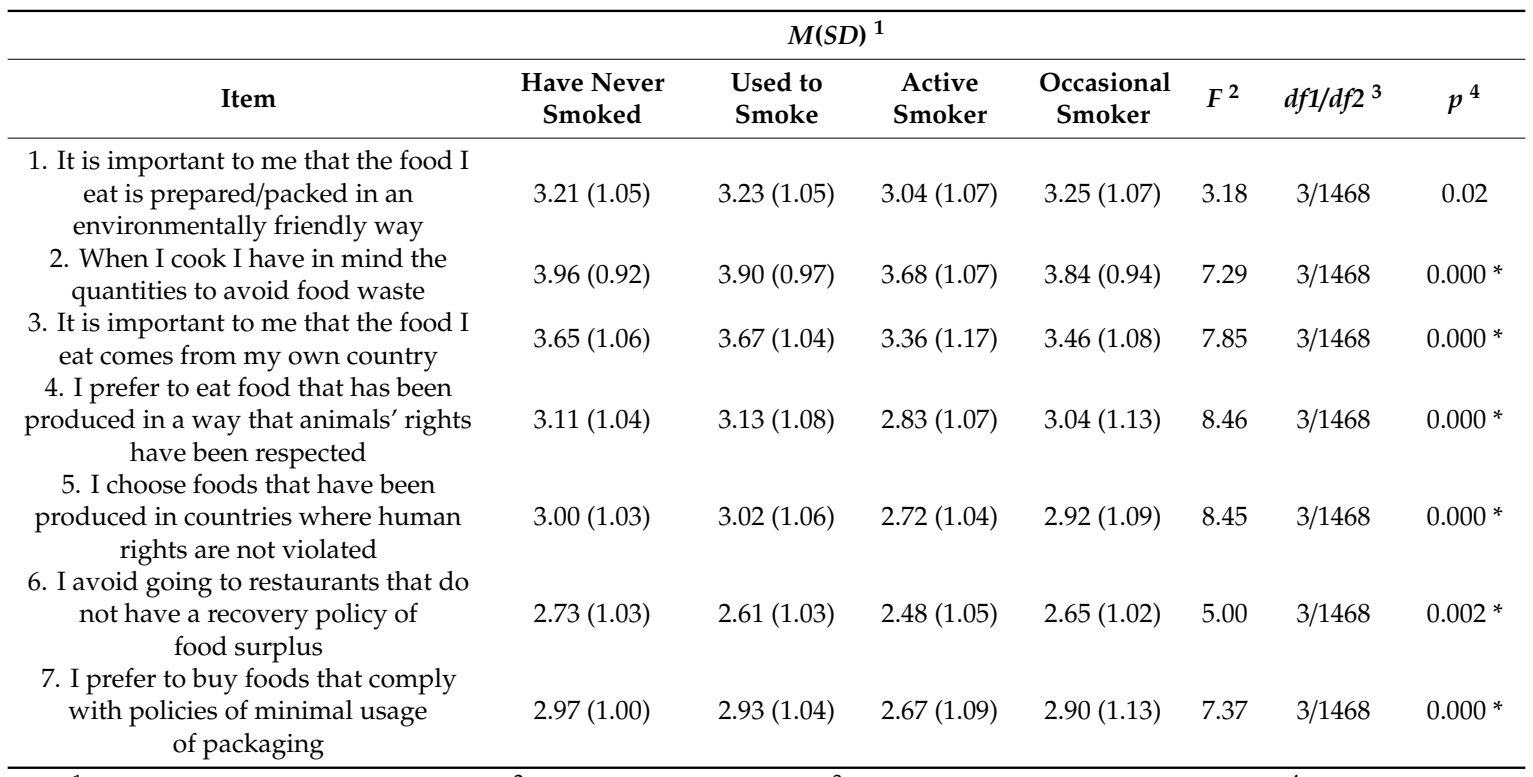

\footnotetext{
${ }^{1}$ Mean value (standard deviation); ${ }^{2}$ Test statistic-ANOVA; ${ }^{3}$ Ratio between degrees of freedom; ${ }^{4}$ Significance. ${ }^{*} p<0.05$.
} 
Table A11. Residential differences in environmental and political determinants of food choices.

\begin{tabular}{|c|c|c|c|c|c|}
\hline \multicolumn{6}{|c|}{$M(S D)^{1}$} \\
\hline Item & $\begin{array}{c}\text { Rural/Suburban } \\
\text { Area }\end{array}$ & Urban Area & $t^{2}$ & $d f^{3}$ & $p^{4}$ \\
\hline $\begin{array}{l}\text { 1. It is important to me that the food I eat is } \\
\text { prepared/packed in an environmentally } \\
\text { friendly way }\end{array}$ & $3.16(1.08)$ & $3.16(1.05)$ & 0.02 & 1301.437 & 0.983 \\
\hline $\begin{array}{l}\text { 2. When I cook I have in mind the } \\
\text { quantities to avoid food waste }\end{array}$ & $3.85(0.97)$ & $3.84(1.00)$ & 0.18 & 1352.298 & 0.867 \\
\hline $\begin{array}{l}\text { 3. It is important to me that the food I eat } \\
\text { comes from my own country }\end{array}$ & $3.63(1.08)$ & 3.47 (1.11) & 2.71 & 1343.548 & 0.007 \\
\hline $\begin{array}{l}\text { 4. I prefer to eat food that has been } \\
\text { produced in a way that animals' rights } \\
\text { have been respected }\end{array}$ & 2.95 (1.09) & $3.06(1.06)$ & 1.95 & 1307.090 & 0.052 \\
\hline $\begin{array}{l}\text { 5. I choose foods that have been produced } \\
\text { in countries where human rights are } \\
\text { not violated }\end{array}$ & $2.90(1.06)$ & $2.90(1.05)$ & 0.06 & 1315.101 & 0.950 \\
\hline $\begin{array}{l}\text { 6. I avoid going to restaurants that do not } \\
\text { have a recovery policy of food surplus }\end{array}$ & $2.62(1.03)$ & $2.61(1.04)$ & 0.22 & 1337.010 & 0.827 \\
\hline $\begin{array}{l}\text { 7. I prefer to buy foods that comply with } \\
\text { policies of minimal usage of packaging }\end{array}$ & $2.88(1.04)$ & $2.84(1.08)$ & 0.76 & 1356.585 & 0.448 \\
\hline
\end{tabular}

Table A12. Employment status differences in environmental and political determinants of food choices.

\begin{tabular}{|c|c|c|c|c|c|}
\hline \multicolumn{6}{|c|}{$M(S D)^{1}$} \\
\hline Item & $\begin{array}{l}\text { Employed/Student } \\
\text { with A Job }\end{array}$ & $\begin{array}{l}\text { Unemployed/ } \\
\text { Student/Retired }\end{array}$ & $t^{2}$ & $d f^{3}$ & $p^{4}$ \\
\hline $\begin{array}{l}\text { 1. It is important to me that the } \\
\text { food I eat is prepared/packed in } \\
\text { an environmentally friendly way }\end{array}$ & $3.21(1.04)$ & $3.10(1.09)$ & 1.94 & 1160.118 & 0.053 \\
\hline $\begin{array}{l}\text { 2. When I cook I have in mind the } \\
\text { quantities to avoid food waste }\end{array}$ & $3.85(0.99)$ & $3.83(0.99)$ & 0.28 & 1212.214 & 0.780 \\
\hline $\begin{array}{l}\text { 3. It is important to me that the } \\
\text { food I eat comes from my } \\
\text { own country }\end{array}$ & $3.55(1.08)$ & $3.51(1.31)$ & 0.71 & 1166.661 & 0.475 \\
\hline $\begin{array}{l}\text { 4. I prefer to eat food that has been } \\
\text { produced in a way that animals' } \\
\text { rights have been respected }\end{array}$ & $3.03(1.07)$ & $2.98(1.09)$ & 0.80 & 1191.729 & 0.422 \\
\hline $\begin{array}{l}\text { 5. I choose foods that have been } \\
\text { produced in countries where } \\
\text { human rights are not violated }\end{array}$ & $2.90(1.05)$ & $2.90(1.07)$ & 0.03 & 1190.334 & 0.973 \\
\hline $\begin{array}{l}\text { 6. I avoid going to restaurants that } \\
\text { do not have a recovery policy of } \\
\text { food surplus }\end{array}$ & $2.63(1.00)$ & $2.59(1.08)$ & 0.70 & 1144.039 & 0.482 \\
\hline $\begin{array}{l}\text { 7. I prefer to buy foods that } \\
\text { comply with policies of minimal } \\
\text { usage of packaging }\end{array}$ & $2.89(1.04)$ & $2.80(1.09)$ & 1.63 & 1165.330 & 0.103 \\
\hline
\end{tabular}

\section{References}

1. Food and Agriculture Organization of the United Nations. Sustainable Food Systems—Concept and Framework; FAO: Rome, Italy, 2018; Available online: http://www.fao.org/policy-support/tools-and-publications/resour ces-details/en/c/1160811/ (accessed on 27 August 2020).

2. Islam, M.S.; Wong, A.T. Climate change and food in/Security: A critical nexus. Environments 2017, 4, 38. [CrossRef] 
3. European Commision. Towards a Sustainable Food System. Available online: https: //ec.europa.eu/info/research-and-innovation/strategy/support-policy-making/scientific-support-eupolicies/group-chief-scientific-advisors/towards-sustainable-food-system_en (accessed on 27 August 2020).

4. Clark, M.A.; Springmann, M.; Hill, J.; Tilman, D. Multiple health and environmental impacts of foods. Proc. Natl. Acad. Sci. USA 2019, 116, 23357-23362. [CrossRef] [PubMed]

5. The State of Food Security and Nutrition in the World 2020: Transforming Food Systems for Affordable Healthy Diets; FAO, IFAD, UNICEF, WFP and WHO: Rome, Italy, 2020; ISBN 978-92-5-132901-6.

6. Aschemann-Witzel, J.; Futtrup Gantriis, R.; Fraga, P.; Perez-Cueto, F.J.A. Plant-based food and protein trend from a business perspective: Markets, consumers, and the challenges and opportunities in the future. Crit. Rev. Food Sci. Nutr. 2020. [CrossRef] [PubMed]

7. Péneau, S.; Fassier, P.; Allès, B.; Kesse-Guyot, E.; Hercberg, S.; Méjean, C. Dilemma between health and environmental motives when purchasing animal food products: Sociodemographic and nutritional characteristics of consumers. BMC Public Health 2017, 17, 876. [CrossRef] [PubMed]

8. Westhoek, H.; Lesschen, J.P.; Rood, T.; Wagner, S.; de Marco, A.; Murphy-Bokern, D.; Leip, A.; van Grinsven, H.; Sutton, M.A.; Oenema, O. Food choices, health and environment: Effects of cutting Europe's meat and dairy intake. Glob. Environ. Change 2014, 26, 196-205. [CrossRef]

9. Macdiarmid, J.I.; Douglas, F.; Campbell, J. Eating like there's no tomorrow: Public awareness of the environmental impact of food and reluctance to eat less meat as part of a sustainable diet. Appetite 2016, 96, 487-493. [CrossRef]

10. Poore, J.; Nemecek, T. Reducing food's environmental impacts through producers and consumers. Science 2018, 360, 987-992. [CrossRef]

11. Chai, B.C.; van der Voort, J.R.; Grofelnik, K.; Eliasdottir, H.G.; Klöss, I.; Perez-Cueto, F.J.A. Which diet has the least environmental impact on our planet? A systematic review of vegan, vegetarian and omnivorous diets. Sustainability 2019, 11, 4110. [CrossRef]

12. Castellini, G.; Savarese, M.; Castiglioni, C.; Graffigna, G. Organic food consumption in Italy: The role of subjective relevance of food as mediator between organic food choice motivation and frequency of organic food consumption. Sustainability 2020, 12, 5367. [CrossRef]

13. Rizzo, G.; Borrello, M.; Guccione, G.D.; Schifani, G.; Cembalo, L. Organic food consumption: The relevance of the health attribute. Sustainability 2020, 12, 595. [CrossRef]

14. Ismael, D.; Ploeger, A. The potential influence of organic food consumption and intention-behavior gap on consumers' subjective wellbeing. Foods 2020, 9, 650. [CrossRef] [PubMed]

15. Macdiarmid, J.I. Seasonality and dietary requirements: Will eating seasonal food contribute to health and environmental sustainability? Proc. Nutr. Soc. 2014, 73, 368-375. [CrossRef] [PubMed]

16. Tobler, C.; Visschers, V.H.M.; Siegrist, M. Eating green. Consumers' willingness to adopt ecological food consumption behaviors. Appetite 2011, 57, 674-682. [CrossRef] [PubMed]

17. Stenmarck, A.; Jensen, C.; Quested, T.; Moates, G. Estimates of European Food Waste Levels; IVL Swedish Environmental Research Institute: Stockholm, Sweden, 2016; Available online: http://www.fao.org/family-f arming/detail/en/c/412647/ (accessed on 27 August 2020).

18. Ilakovac, B.; Iličković, M.; Voća, N. Food waste drivers in Croatian households. J. Cent. Eur. Agric. 2018, 19, 678-709. [CrossRef]

19. Guillard, V.; Gaucel, S.; Fornaciari, C.; Angellier-Coussy, H.; Buche, P.; Gontard, N. The next generation of sustainable food packaging to preserve our environment in a circular economy context. Front. Nutr. 2018, 5. [CrossRef]

20. Ketelsen, M.; Janssen, M.; Hamm, U. Consumers' response to environmentally-friendly food packaging-A systematic review. J. Clean Prod. 2020, 254, 120123. [CrossRef]

21. National Research Council. Individual, household, and environmental factors affecting food choices. In Supplemental Nutrition Assistance Program: Examining the Evidence to Define Benefit Adequacy; Caswell, J.A., Yaktine, A.L., Eds.; National Academies Press: Washington, DC, USA, 2013.

22. de Boer, J.; Aiking, H. Prospects for pro-environmental protein consumption in Europe: Cultural, culinary, economic and psychological factors. Appetite 2018, 121, 29-40. [CrossRef]

23. Gifford, R.; Nilsson, A. Personal and social factors that influence pro-environmental concern and behaviour: A review. Int. J. Psychol. 2014, 49, 141-157. [CrossRef] 
24. Ferrão, A.C.; Guine, R.P.F.; Correia, P.M.R.; Ferreira, M.; Lima, J.D.J. Development of a questionnaire to assess people's food choices determinants. Curr. Nutr. Food Sci. 2019, 15, 281-295. [CrossRef]

25. Guiné, R.P.F.; Ferrão, A.C.; Ferreira, M.; Correia, P.; Mendes, M.; Bartkiene, E.; Szúcs, V.; Tarcea, M.; Sarić, M.M.; Černelič-Bizjak, M.; et al. Influence of sociodemographic factors on eating motivations-Modelling through artificial neural networks (ANN). Int. J. Food Sci. Nutr. 2019, 1-14. [CrossRef]

26. Guiné, R.P.F.; Bartkiene, E.; Szúcs, V.; Tarcea, M.; Ljubičić, M.; Černelič-Bizjak, M.; Isoldi, K.; EL-Kenawy, A.; Ferreira, V.; Straumite, E.; et al. Study about food choice determinants according to six types of conditioning motivations in a sample of 11,960 participants. Foods 2020, 9, 888. [CrossRef] [PubMed]

27. Ferrão, A.C.; Guiné, R.P.F.; Ferreira, P.C. and M. Influence of environmental and political determinants on food choices in a sample of Portuguese population. Curr. Nutr. Food Sci. 2020, 16, 689-697. [CrossRef]

28. Horn, J.L. A rationale and test for the number of factors in factor analysis. Psychometrika 1965, 30, $179-185$. [CrossRef] [PubMed]

29. Samuels, P. Advice on Exploratory Factor Analysis. Available online: https://www.researchgate.net/publicati on/319165677_Advice_on_Exploratory_Factor_Analysis (accessed on 7 September 2020).

30. Watkins, M.W. Exploratory factor analysis: A guide to best practice. J. Black Psychol. 2018, 44, $219-246$. [CrossRef]

31. Kohr, R.L.; Games, P.A. Robustness of the analysis of variance, the Welch procedure and a box procedure to heterogeneous variances. J. Exp. Educ. 1974, 43, 61-69. [CrossRef]

32. Pestana, M.H.; Gageiro, J.N. Análise de Dados para Ciências Sociais-A Complementaridade do SPSS, 6th ed.; Edições Sílabo: Lisboa, Portugal, 2008.

33. Domazet, M.; Dolenec, D.; Ančić, B. We Need to Change: Mapping Croatia's Potential for Sustainable Development; Heinrich Böll Stiftung: Zagreb, Croatia, 2012.

34. European Commission; Directorate-General Environment. The Environmental Implementation Review; Publications Office: Luxembourg, 2019; ISBN 978-92-79-99195-0.

35. Zlatar-Vulić, R. Consumers' perception of corporate social responsibility in food retailing in the Republic of Croatia. Socijalna Ekologija: Časopis za Ekološku Misao i Sociologijska Istraživanja Okoline 2020, 29, $27-47$. [CrossRef]

36. Secondi, L.; Principato, L.; Laureti, T. Household food waste behaviour in EU-27 countries: A multilevel analysis. Food Policy 2015, 56, 25-40. [CrossRef]

37. Quested, T.E.; Marsh, E.; Stunell, D.; Parry, A.D. Spaghetti soup: The complex world of food waste behaviours. Resour. Conserv. Recycl. 2013, 79, 43-51. [CrossRef]

38. Adjusted Gross Disposable Income of Households per Capita-Eurostat. Available online: https://ec.europa. eu/eurostat/web/products-datasets/-/sdg_10_20 (accessed on 4 September 2020).

39. Casado-Aranda, L.-A.; Sánchez-Fernández, J.; Ibáñez-Zapata, J.-Á.; Liébana-Cabanillas, F.J. How consumer ethnocentrism modulates neural processing of domestic and foreign products: A neuroimaging study. J. Retail. Consum. Serv. 2020, 53, 101961. [CrossRef]

40. Pekkanen, T.-L.; Penttilä, V. The responsibility of an ethnocentric consumer-Nationalistic, patriotic or environmentally conscientious? A critical discourse analysis of "buy domestic" campaigns. Int. Mark. Rev. 2020. [CrossRef]

41. Kupujmo Hrvatsko. Available online: http://kupujmohrvatsko.hgk.hr/ (accessed on 3 September 2020).

42. Renko, N.; Crnjak Karanović, B.; Matić, M. Influence of consumer ethnocentrism on purchase intentions: Case of Croatia. Ekonomska Misao i Praksa 2012, 2, 29-544.

43. Blankenberg, A.-K.; Alhusen, H. On the determinants of pro-environmental behavior: A guide for further investigations. SSRN Electron. J. 2018. [CrossRef]

44. Janssens, K.; Lambrechts, W.; van Osch, A.; Semeijn, J. How consumer B in daily food provisioning affects food waste at household level in The Netherlands. Foods 2019, 8, 428. [CrossRef] [PubMed]

45. Partearroyo, T.; Samaniego-Vaesken, M.d.L.; Ruiz, E.; Aranceta-Bartrina, J.; Gil, Á.; González-Gross, M.; Ortega, R.M.; Serra-Majem, L.; Varela-Moreiras, G. Plate waste generated by Spanish households and out-of-home consumption: Results from the ANIBES study. Nutrients 2020, 12, 1641. [CrossRef] [PubMed]

46. Szakos, D.; Szabó-Bódi, B.; Kasza, G. Consumer awareness campaign to reduce household food waste based on structural equation b modeling in Hungary. Environ. Sci. Pollut. Res. 2020. [CrossRef] [PubMed]

47. Limon, M.R.; Villarino, C.B.J. Knowledge, attitudes and practices on household food waste: Bases for formulation of a recycling system. Glob. J. Environ. Sci. Manag. 2020, 6, 323-340. [CrossRef] 
48. Koivupuro, H.-K.; Hartikainen, H.; Silvennoinen, K.; Katajajuuri, J.-M.; Heikintalo, N.; Reinikainen, A.; Jalkanen, L. Influence of socio-demographical, behavioural and attitudinal factors on the amount of avoidable food waste generated in Finnish households. Int. J. Consum. Stud. 2012, 36, 183-191. [CrossRef]

49. Hazuchova, N.; Antosova, I.; Stavkova, J. Food wastage as a display of consumer behaviour. J. Compet. 2020, 12, 51-66. [CrossRef]

50. Jiménez-Guerrero, J.F.; Pérez-Mesa, J.C.; Galdeano-Gómez, E. Alternative proposals to measure consumer ethnocentric B: A narrative literature review. Sustainability 2020, 12, 2216. [CrossRef]

51. Longhi, S. Individual Pro-Environmental Behaviour in the Household Context; ISER Working Paper Series; Institute for Social and Economic Research: Colchester, UK, 2013.

52. Li, D.; Zhao, L.; Ma, S.; Shao, S.; Zhang, L. What influences an individual's pro-environmental behavior? A literature review. Resour. Conserv. Recycl. 2019, 146, 28-34. [CrossRef]

53. Herzog, H.A. Gender differences in human-animal interactions: A review. Anthrozoös 2007, $20,7-21$. [CrossRef]

54. Herzog, H.A.; Golden, L.L. Moral emotions and social activism: The case of animal rights. J. Soc. Issues 2009, 65, 485-498. [CrossRef]

55. Miranda-de la Lama, G.C.; Estévez-Moreno, L.X.; Sepúlveda, W.S.; Estrada-Chavero, M.C.; Rayas-Amor, A.A.; Villarroel, M.; María, G.A. Mexican consumers' perceptions and attitudes towards farm animal welfare and willingness to pay for welfare friendly meat products. Meat Sci. 2017, 125, 106-113. [CrossRef] [PubMed]

56. McKendree, M.G.S.; Croney, C.C.; Widmar, N.J.O. Effects of demographic factors and information sources on United States consumer perceptions of animal welfare. J. Anim. Sci. 2014, 92, 3161-3173. [CrossRef] [PubMed]

57. Cornish, A.; Raubenheimer, D.; McGreevy, P. What we know about the public's level of concern for farm animal welfare in food production in developed countries. Animals 2016, 6, 74. [CrossRef]

58. Neilson, L.A. Boycott or buycott? Understanding political consumerism. J. Consum. Behav. 2010, 9, $214-227$. [CrossRef]

59. Principato, L.; Secondi, L.; Pratesi, C.A. Reducing food waste: An investigation on the behaviour of Italian youths. Br. Food J. 2015, 117, 731-748. [CrossRef]

60. Visschers, V.H.M.; Wickli, N.; Siegrist, M. Sorting out food waste behaviour: A survey on the motivators and barriers of self-reported amounts of food waste in households. J. Environ. Psychol. 2016, 45, 66-78. [CrossRef]

61. Bilska, B.; Tomaszewska, M.; Kołożyn-Krajewska, D. Analysis of the Bs of Polish consumers in relation to food waste. Sustainability 2019, 12, 304. [CrossRef]

62. Silvennoinen, K.; Katajajuuri, J.-M.; Hartikainen, H.; Heikkilä, L.; Reinikainen, A. Food waste volume and composition in Finnish households. Br. Food J. 2014, 116, 1058-1068. [CrossRef]

63. Porpino, G. Household food waste B: Avenues for future research. JACR 2016, 1, 41-51. [CrossRef]

64. Cantaragiu, R. The impact of gender on food waste at the consumer level. J. Studia Universitatis "Vasile Goldis" Arad-Econ. Ser. 2019, 29, 41-57. [CrossRef]

65. Faver, C.A.; Muñoz, J.D. Orientations to nonhuman animal welfare: A view from the border. Soc. Anim. 2014, 22, 372-389. [CrossRef]

66. Cornish, A.R.; Briley, D.; Wilson, B.J.; Raubenheimer, D.; Schlosberg, D.; McGreevy, P.D. The price of good welfare: Does informing consumers about what on-package labels mean for animal welfare influence their purchase intentions? Appetite 2020, 148, 104577. [CrossRef]

67. Clark, B.; Stewart, G.B.; Panzone, L.A.; Kyriazakis, I.; Frewer, L.J. Citizens, consumers and farm animal welfare: A meta-analysis of willingness-to-pay studies. Food Policy 2017, 68, 112-127. [CrossRef]

68. Williams, H.; Wikström, F.; Otterbring, T.; Löfgren, M.; Gustafsson, A. Reasons for household food waste with special attention to packaging. J. Clean Prod. 2012, 24, 141-148. [CrossRef]

69. Abdelradi, F. Food waste behaviour at the household level: A conceptual framework. Waste Manag. 2018, 71, 485-493. [CrossRef]

70. Mattar, L.; Abiad, M.G.; Chalak, A.; Diab, M.; Hassan, H. Attitudes and bs shaping household food waste generation: Lessons from Lebanon. J. Clean Prod. 2018, 198, 1219-1223. [CrossRef]

71. Hopwood, C.J.; Bleidorn, W.; Schwaba, T.; Chen, S. Health, environmental, and animal rights motives for vegetarian eating. PLOS ONE 2020, 15. [CrossRef]

72. Miki, A.J.; Livingston, K.A.; Karlsen, M.C.; Folta, S.C.; McKeown, N.M. Using evidence mapping to examine motivations for following plant-based diets. Curr. Dev. Nutr. 2020, 4. [CrossRef] 
73. Netuveli, G.; Watts, P. Pro-environmental behaviours and attitudes are associated with health, wellbeing and life satisfaction in multiple occupancy households in the UK household longitudinal study. Popul. Environ. 2020, 41, 347-371. [CrossRef]

74. Slopen, N.; Kontos, E.Z.; Ryff, C.D.; Ayanian, J.Z.; Albert, M.A.; Williams, D.R. Psychosocial stress and cigarette smoking persistence, cessation, and relapse over 9-10 years: A prospective study of middle-aged adults in the United States. Cancer Causes Control 2013, 24, 1849-1863. [CrossRef] [PubMed]

75. Bollani, L.; Bonadonna, A.; Peira, G. The millennials' concept of sustainability in the food sector. Sustainability 2019, 11, 2984. [CrossRef]

Publisher's Note: MDPI stays neutral with regard to jurisdictional claims in published maps and institutional affiliations.

(C) 2020 by the authors. Licensee MDPI, Basel, Switzerland. This article is an open access article distributed under the terms and conditions of the Creative Commons Attribution (CC BY) license (http://creativecommons.org/licenses/by/4.0/). 